KRZYSZTOF HAJDER

Poznań

\title{
Bezrobocie w Unii Europejskiej w świetle kryzysu gospodarczego lat 2008-2013
}

Bezrobocie stanowi immanentną cechę gospodarki rynkowej. Jego poziom w istotnej mierze jest związany z koniunkturą gospodarczą na danym rynku. W związku z tym, zarówno dynamika wzrostu gospodarczego wpływa na poziom zatrudnienia, jak i zmiany rozmiarów zatrudnienia determinują tempo wzrostu gospodarczego. Stopa bezrobocia jest zatem jednym z najważniejszych mierników, charakteryzujących kondycję gospodarki. Od lat 90 . we współczesnych gospodarkach rynkowych obserwować można rysującą się tendencję uelastyczniania rynków pracy. Pod wpływem konkurencji światowej, rządy poszczególnych państw starają się dostosować się do aktualnej sytuacji rynkowej, redukując m.in. koszty pracy. $Z$ tych samych względów, pracodawcy wykorzystując możliwości, które daje im elastyczny rynek pracy swobodnie regulują poziom zatrudnienia i wysokość płac. W konsekwencji, bezrobocie traktować należy, jako miernik stanu gospodarki, który obrazuje skutki kształtowania się kondycji gospodarki i głównych jej determinantów. Jak wykazały dotychczasowe badania, dynamika Produktu Krajowego Brutto, jako jednego z podstawowych mierników rozwoju gospodarczego jest ściśle związana z kształtowaniem się równowagi na rynku pracy ${ }^{1}$ (Zięba, 2011). Nie bez wpływu dla skuteczności ograniczania bezrobocia, pozostają również podejmowane działania $\mathrm{w}$ ramach aktywnych programów walki z tym zjawiskiem.

W świetle współczesnego kryzysu gospodarczego warto dokonać analizy kształtowania się sytuacji na rynkach pracy w UE i w wybranych państwach świata począwszy od roku 2008. Pozwala to na zbadanie zmian poziomu zatrudnienia pod wpływem zarówno dynamiki recesji, jak i stosowanej polityki antyrecesyjnej.

Załamanie rozwoju gospodarczego silnie przełożyło się na wzrost bezrobocia. Jak wynika z szacunków Międzynarodowego Funduszu Walutowego, światowy kryzys ekonomiczny doprowadził do likwidacji 30 milionów miejsc pracy, a potrzeby w nadchodzących latach szacowane są na 400 milionów nowych miejsc pracy (Strauss-Kahn 2011). Podczas, gdy w okresie od 1998 do 2008 roku następowało powolne ograniczanie rozmiarów bezrobocia w państwach Unii Europejskiej, któremu towarzyszył systematyczny wzrost Produktu Krajowego Brutto, to wraz z nadejściem recesji gospodarczej (a w niektórych państwach spowolnienia rozwoju np. w Polsce) w sposób bezpośredni doszło do wzrostu poziomu bezrobocia. Zmiany trendu kształtowania się stopy bezrobocia w Unii Europejskiej, Japonii i Stanach Zjednoczonych prezentuje wykres 1 .

1 Okun`s law. 
Wykres 1. Stopa bezrobocia w UE, Japonii i Stanach Zjednoczonych w latach 2000-2013

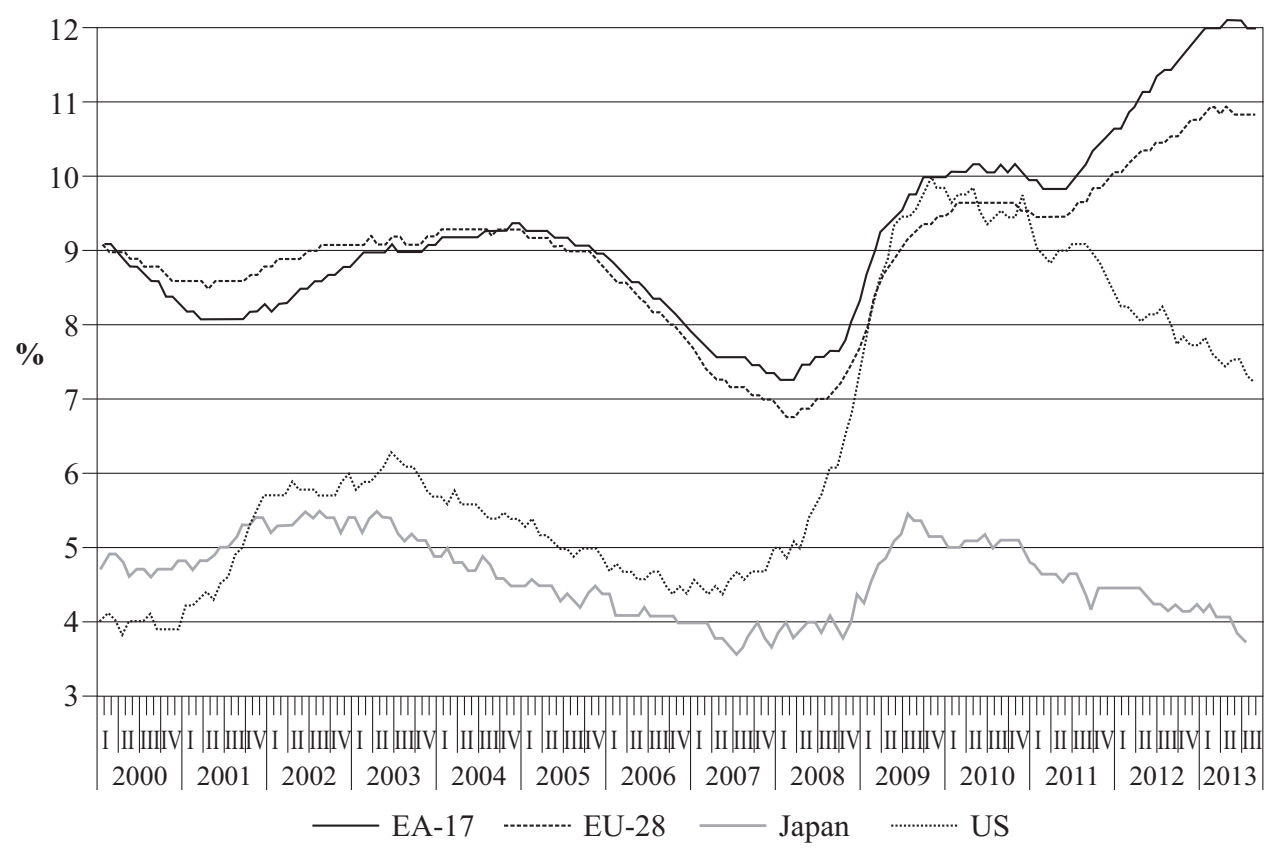

Źródlo: http://epp.eurostat.ec.europa.eu/statistics_explained/index.php/Unnemployment_statistics, dostęp: 5.10.2013.

Trendy zarysowane na powyższym wykresie wskazują, że załamanie gospodarcze na świecie spowodowało bardzo dynamiczny wzrost bezrobocia. Widać jednak, że wzrost bezrobocia kształtował się bardzo nierównomiernie. Najsilniej bezrobocie wzrosło (o ok. 5,5 p.p.) w Stanach Zjednoczonych dorównując rozmiarom notowany w UE. Warto zauważyć, że amerykański rynek pracy należy do wysoce elastycznych i stąd w okresie dekoniunktury następuje bardzo dynamiczna redukcja zatrudnienia. Najmniejszy wzrost (o ok. 1,5 p.p.) zanotowała z kolei Japonia. W tym przypadku, mimo wdrażanego procesu uelastyczniania, nadal można mówić o jednym z najbardziej sztywnych rynków pracy wśród rynkowych systemów gospodarczych. W Unii Europejskiej w pierwszej fazie kryzysu bezrobocie wzrosło o ok. 2,5 p.p., jednak po szybkim ,wygaszeniu” programów stymulacyjnych nastąiła dalsza redukcja zatrudnienia i bezrobocie wzrosło o kolejne 2 p.p. W tym samym okresie kontynuacja polityki interwencjonistycznej w Stanach Zjednoczonych przyniosła redukcję bezrobocia o blisko 3 p.p., sprowadzając jego stopę ponownie znacznie poniżej poziomu notowanego w Unii Europejskiej. Z punktu widzenia stabilizacji sytuacji na rynku pracy trudno pozytywnie ocenić wstrzemięźliwość stymulacyjną rządów europejskich. Taki kierunek polityki można jednak tłumaczyć obawami o dynamiczny przyrost zadłużenia i negatywne tego efekty w przyszłości.

Poniższe zestawienie dynamiki PKB wskazuje na zróżnicowanie zmian poziomów wzrostu gospodarczego w poszczególnych państwach UE (tabela 1). Pozwala ono również, uwzględniając także dane zawarte w tabeli 2 zaobserwować zależność dynamiki PKB i zmian rozmiarów bezrobocia. 
Tabela 1

Dynamika PKB w państwach UE (rok do roku w \%)

\begin{tabular}{|c|c|c|c|c|c|c|c|c|c|c|}
\hline Państwo Rok & 2005 & 2006 & 2007 & 2008 & 2009 & 2010 & 2011 & 2012 & 2013* & 2014 * \\
\hline $\begin{array}{l}\text { Unia Europejska } \\
\text { ( } 27 \text { państw) }\end{array}$ & 2,2 & 3,4 & 3,2 & 0,4 & $-4,5$ & 2,0 & 1,7 & $-0,4$ & $-0,1$ & 1,4 \\
\hline $\begin{array}{l}\text { Unia Europejska } \\
\text { (15 państw) }\end{array}$ & 2,0 & 3,2 & 3,0 & 0,1 & $-4,5$ & 2,0 & 1,5 & $-0,5$ & $-0,2$ & 1,4 \\
\hline Strefa Euro (17 państw) & 1,7 & 3,2 & 3,0 & 0,4 & $-4,4$ & 2,0 & 1,5 & $-0,6$ & $-0,4$ & 1,2 \\
\hline Strefa Euro (12 państw) & 1,7 & 3,2 & 2,9 & 0,3 & $-4,4$ & 1,9 & 1,5 & $-0,7$ & $-0,4$ & 1,2 \\
\hline Belgia & 1,8 & 2,7 & 2,9 & 1,0 & $-2,8$ & 2,3 & 1,8 & $-0,1$ & 0,0 & 1,2 \\
\hline Bułgaria & 6,4 & 6,5 & 6,4 & 6,2 & $-5,5$ & 0,4 & 1,8 & 0,8 & 0,9 & 1,7 \\
\hline Republika Czeska & 6,8 & 7,0 & 5,7 & 3,1 & $-4,5$ & 2,5 & 1,8 & $-1,0$ & $-0,4$ & 1,6 \\
\hline Dania & 2,4 & 3,4 & 1,6 & $-0,8$ & $-5,7$ & 1,6 & 1,1 & $-0,4$ & 0,7 & 1,7 \\
\hline Niemcy & 0,7 & 3,7 & 3,3 & 1,1 & $-5,1$ & 4,0 & 3,3 & 0,7 & 0,4 & 1,8 \\
\hline Estonia & 8,9 & 10,1 & 7,5 & $-4,2$ & $-14,1$ & 2,6 & 9,6 & 3,9 & 3,0 & 4,0 \\
\hline Irlandia & 6,1 & 5,5 & 5,0 & $-2,2$ & $-6,4$ & $-1,1$ & 2,2 & 0,2 & 1,1 & 2,2 \\
\hline Grecja & 2,3 & 5,5 & 3,5 & $-0,2$ & $-3,1$ & $-4,9$ & $-7,1$ & $-6,4$ & $-4,2$ & 0,6 \\
\hline Hiszpania & 3,6 & 4,1 & 3,5 & 0,9 & $-3,8$ & $-0,2$ & 0,1 & $-1,6$ & $-1,5$ & 0,9 \\
\hline Francja & 1,8 & 2,5 & 2,3 & $-0,1$ & $-3,1$ & 1,7 & 2,0 & 0,0 & $-0,1$ & 1,1 \\
\hline Chorwacja & 4,3 & 4,9 & 5,1 & 2,1 & $-6,9$ & $-2,3$ & 0,0 & $-2,0$ & $-1,0$ & 0,2 \\
\hline Włochy & 0,9 & 2,2 & 1,7 & $-1,2$ & $-5,5$ & 1,7 & 0,5 & $-2,5$ & $-1,3$ & 0,7 \\
\hline Cypr & 3,9 & 4,1 & 5,1 & 3,6 & $-1,9$ & 1,3 & 0,4 & $-2,4$ & $-8,7$ & $-3,9$ \\
\hline Łotwa & 10,1 & 11,0 & 10,0 & $-2,8$ & $-17,7$ & $-1,3$ & 5,3 & 11,4 & 3,8 & 4,1 \\
\hline Litwa & 7,8 & 7,8 & 9,8 & 2,9 & $-14,8$ & 1,6 & 6,0 & 3,7 & 3,1 & 3,6 \\
\hline Luxemburg & 5,3 & 4,9 & 6,6 & $-0,7$ & $-5,6$ & 3,1 & 1,9 & $-0,2$ & 0,8 & 1,6 \\
\hline Węgry & 4,0 & 3,9 & 0,1 & 0,9 & $-6,8$ & 1,1 & 1,6 & $-1,7$ & 0,2 & 1,4 \\
\hline Malta & 3,6 & 2,6 & 4,1 & 3,9 & $-2,8$ & 4,0 & 1,6 & 0,8 & 1,4 & 1,8 \\
\hline Holandia & 2,0 & 3,4 & 3,9 & 1,8 & $-3,7$ & 1,5 & 0,9 & $-1,2$ & $-0,8$ & 0,9 \\
\hline Austria & 2,4 & 3,7 & 3,7 & 1,4 & $-3,8$ & 1,8 & 2,8 & 0,9 & 0,6 & 1,8 \\
\hline Polska & 3,6 & 6,2 & 6,8 & 5,1 & 1,6 & 3,9 & 4,5 & 1,9 & 1,1 & 2,2 \\
\hline Portugalia & 0,8 & 1,4 & 2,4 & 0,0 & $-2,9$ & 1,9 & $-1,3$ & $-3,2$ & $-2,3$ & 0,6 \\
\hline Rumunia & 4,2 & 7,9 & 6,3 & 7,3 & $-6,6$ & $-1,1$ & 2,2 & 0,7 & 1,6 & 2,2 \\
\hline Słowenia & 4,0 & 5,8 & 7,0 & 3,4 & $-7,9$ & 1,3 & 0,7 & $-2,5$ & $-2,0$ & $-0,1$ \\
\hline Słowacja & 6,7 & 8,3 & 10,5 & 5,8 & $-4,9$ & 4,4 & 3,2 & 2,0 & 1,0 & 2,8 \\
\hline Finlandia & 2,9 & 4,4 & 5,3 & 0,3 & $-8,5$ & 3,4 & 2,7 & $-0,8$ & 0,3 & 1,0 \\
\hline Szwecja & 3,2 & 4,3 & 3,3 & $-0,6$ & $-5,0$ & 6,6 & 2,9 & 1,0 & 1,5 & 2,5 \\
\hline Wielka Brytania & 3,2 & 2,8 & 3,4 & $-0,8$ & $-5,2$ & 1,7 & 1,1 & 0,1 & 0,6 & 1,7 \\
\hline
\end{tabular}

* Prognoza.

Źródło: http://epp.eurostat.ec.europa.eu/tgm/table.do?tab=table\&init=1\&plugin=1\&language=en\&pcode=tec00115, dstęp: 6.10.2013. 
O kształtowaniu się rozmiarów bezrobocia decyduje oczywiście nie tylko koniunktura gospodarcza. Obecnie, wśród najważniejszych determinantów bezrobocia wymienia się zasady i stopień regulacji funkcjonowania rynku pracy. Można jednak sformułować tezę, że powyższe i inne czynniki o charakterze regulacyjnym w dobie kryzysu tracą na znaczeniu, ustępując miejsca efektom polityki stymulacyjnej realizowanej przez poszczególne rządy.

Zestawienie danych zawartych w tabelach 1. i 2. wskazuje, że największy wzrost bezrobocia zanotowano w państwach nadbałtyckich oraz Irlandii, Grecji i na Cyprze, gdzie jego stopa wzrosła ponad 3-krotnie, a nawet jak w przypadku Litwy 5-krotnie. Łatwo zauważyć, że tak dynamicznym wzrostom bezrobocia, towarzyszyły najwyższe wskaźniki recesji gospodarczej. Gospodarki tych państw skurczyły się o blisko $20 \%$ a w przypadku Łotwy nawet o ponad 20\%. Wyjątek pod tym względem stanowi Irlandia, gdzie recesja nie przekroczyła nawet $10 \%$, a bezrobocie się potroiło. Wnioskować można, że stanowi to negatywny efekt wysokiej elastyczności rynku pracy bez zachowania mechanizmów bezpieczeństwa zatrudnienia (flexicurity), co decyduje o silnej wrażliwości na koniunkturę gospodarczą.

Warto podkreślić, że od początku kryzysu w Unii Europejskiej stopa bezrobocia ogółem niemal systematycznie wzrastała (tabela 2.). W 2013 roku jego rozmiary ukształtowały się na poziomie o ponad połowę wyższym, niż w 2007 roku. Dla porównania, gospodarka amerykańska w tym samym okresie, najpierw zanotowała podwojenie stopy bezrobocia, a od 2010 roku notuje stały jej spadek (w $2007 \mathrm{r}$. stopa bezrobocia w UE była wyższa, niż w Stanach Zjednoczonych o 1,9 p.p. a w 2013 r. już o 3,6 p.p.). Powyższe dane pozwalają sformułować wniosek, że Amerykanie skuteczniej poradzili sobie z kryzysem, mimo silniejszego wstrząsu, który dotknął gospodarkę Stanów Zjednoczonych. Decydujący wpływ na takie zróżnicowanie pomiędzy powyższymi gospodarkami wywarło wspomniane, szybkie odstapienie od realizacji pakietów stymulacyjnych w UE. Obawy o narastający dług publiczny nie pozwoliły na kontynuację przywracania dynamiki wzrostu gospodarczego, a tym samym na zdecydowaną poprawę sytuacji na rynku pracy.

Tabela 2

Stopy bezrobocia w wybranych państwach w latach 2007-2013

\begin{tabular}{||l|c|c|c|c|c|c|c||}
\hline \hline Grudzień & $\mathbf{2 0 0 7}$ & $\mathbf{2 0 0 8}$ & $\mathbf{2 0 0 9}$ & $\mathbf{2 0 1 0}$ & $\mathbf{2 0 1 1}$ & $\mathbf{2 0 1 2}$ & $\mathbf{2 0 1 3}$ \\
\hline \multicolumn{1}{|c|}{1} & 2 & 3 & 4 & 5 & 6 & 7 & 8 \\
\hline Unia Europejska (27 państw) & 6,9 & 7,7 & 9,5 & 9,6 & 10,0 & 10,8 & 10,9 \\
\hline Srefa Euro (17 państw) & 7,4 & 8,3 & 10,0 & 10,0 & 10,7 & 11,9 & 12,0 \\
\hline Bułgaria & 6,2 & 5,5 & 8,4 & 11,3 & 11,7 & 12,6 & 13,0 \\
\hline Republika Czeska & 4,8 & 4,7 & 7,3 & 7,0 & 6,6 & 7,2 & 6,9 \\
\hline Dania & 3,4 & 4,1 & 7,0 & 7,6 & 7,8 & 7,3 & 6,6 \\
\hline Niemcy & 8,2 & 7,3 & 7,6 & 6,6 & 5,6 & 5,4 & 5,2 \\
\hline Estonia & 4,3 & 9,3 & 16,9 & 14,2 & 11,0 & 9,8 & $:$ \\
\hline Irlandia & 5,0 & 8,5 & 13,1 & 14,9 & 15,0 & 14,0 & 13,6 \\
\hline Grecja & 8,0 & 8,6 & 10,4 & 14,5 & 21,4 & 26,1 & $:$ \\
\hline \hline
\end{tabular}




\begin{tabular}{|l|r|r|r|r|r|r|c||}
\hline \multicolumn{1}{|c|}{1} & 2 & 3 & 4 & 5 & 6 & 7 & 8 \\
\hline Hiszpania & 8,8 & 14,9 & 19,2 & 20,5 & 23,2 & 26,2 & 26,2 \\
\hline Francja & 7,7 & 8,3 & 9,9 & 9,6 & 9,8 & 10,7 & 11,0 \\
\hline Chorwacja & 9,4 & 8,6 & 9,6 & 12,3 & 14,3 & 17,7 & 16,9 \\
\hline Włochy & 6,5 & 6,8 & 8,3 & 8,2 & 9,5 & 11,4 & 12,2 \\
\hline Cypr & 3,8 & 3,8 & 6,6 & 6,0 & 9,7 & 13,7 & 16,9 \\
\hline Lotwa & 6,0 & 10,9 & 20,9 & 18,0 & 15,4 & 14,0 & $:$ \\
\hline Litwa & 3,5 & 8,6 & 16,9 & 17,5 & 13,6 & 12,7 & 12,3 \\
\hline Weggry & 8,0 & 8,3 & 10,7 & 11,0 & 10,9 & 11,0 & $:$ \\
\hline Holandia & 3,3 & 3,1 & 4,4 & 4,3 & 4,9 & 5,8 & 7,0 \\
\hline Austria & 4,0 & 4,4 & 4,6 & 4,2 & 4,1 & 4,7 & 4,9 \\
\hline Polska & 8,2 & 7,0 & 9,0 & 9,5 & 9,9 & 10,4 & 10,3 \\
\hline Portugalia & 8,5 & 8,9 & 11,2 & 12,2 & 14,5 & 17,3 & 16,5 \\
\hline Rumunia & 6,1 & 5,8 & 7,4 & 7,2 & 7,4 & 6,7 & 7,5 \\
\hline Słowenia & 4,7 & 4,3 & 6,4 & 8,0 & 8,6 & 9,7 & 10,4 \\
\hline Słowacja & 10,5 & 9,1 & 14,4 & 13,9 & 14,0 & 14,4 & 14,0 \\
\hline Finlandia & 6,5 & 6,9 & 8,7 & 8,0 & 7,6 & 8,0 & 8,0 \\
\hline Szwecja & 6,0 & 6,8 & 9,0 & 8,0 & 7,8 & 8,0 & 8,0 \\
\hline Wielka Brytania & 5,1 & 6,5 & 7,7 & 7,8 & 8,3 & 7,7 & $:$ \\
\hline Islandia & 2,4 & 5,3 & 7,4 & 7,8 & 6,4 & 5,4 & 5,5 \\
\hline Norwegia & 2,4 & 2,9 & 3,3 & 3,4 & 3,3 & 3,5 & $:$ \\
\hline Turcja & 9,0 & 11,6 & 11,5 & 9,6 & 8,2 & 8,5 & $:$ \\
\hline Stany Zjednoczone & 5,0 & 7,3 & 9,9 & 9,4 & 8,5 & 7,8 & 7,3 \\
\hline Japonia & 3,7 & 4,4 & 5,2 & 4,9 & 4,5 & 4,3 & $:$ \\
\hline \hline
\end{tabular}

Źródło: http://epp.eurostat.ec.europa.eu/tgm/table.do?tab=table\&language=en\&pcode=teilm020\&tableSelection=1\&plugin=1, dostęp: 5.10 .2013 .

Bardzo ciekawy przykład stanowi Hiszpania, gdzie stopa bezrobocia osiągnęła najwyższy w UE poziom $26,2 \%$, przy jednoczesnej relatywnie niewysokiej ${ }^{2}$ skali recesji. W tym przypadku można sformułować wniosek, że polityka ograniczania bezrobocia zastosowana w okresie rządów J. Aznara, oparta na reformach uelastyczniających rynek pracy zrównoważyła hiszpański rynek pracy jedynie w okresie korzystnej koniunktury gospodarczej. Osiaggnięte sukcesy w zwalczaniu bezrobocia opierały się głównie na wdrażaniu modelu elastycznego zatrudnienia z wykorzystaniem np. krótkoterminowych kontraktów zatrudnienia. Stworzono w ten sposób, niestabilny rynek pracy z największym w UE udziałem nisko płatnych tzw. „umów śmieciowych”, czyli takich, które ich posiadaczom nie zapewniają żadnych gwarancji bezpieczeństwa i stabilności. Ponadto dodać należy, że dominacja takiej formy zatrudnienia nie służy podnoszeniu produktywności gospodarki, gdyż pracodawcy tracą zainteresowanie

${ }^{2}$ Najsilniej gospodarka hiszpańska skurczyła się w 2009 roku o $-3,8 \%$, co stanowiło jednak zwiastun kolejnych lat „pod kreską" rozwoju. 
inwestowaniem w kapitał ludzki, ograniczając np. wydatki na podnoszenie kwalifikacji swoich pracowników. Nie zgadzają się z tym podejściem ekonomiści nurtu neoliberalnego, którzy uznają że dzięki elastyczności zatrudnienia firmy są bardziej konkurencyjne, gdyż mogą zatrudniać i zwalniać zgodnie z rytmem koniunktury gospodarczej (Choragwicka 2005; Czepulis-Rutkowska 2005). Podkreślić należy, że taka konstrukcja modelu zatrudnienia zdecydowała, że wyhamowanie strumieni unijnych środków pomocowych, przekazywanych Hiszpanii (w wyniku ,dużego rozszerzenia” Hiszpania przestała spełniać kryteria, pozwalające na pozyskiwanie środków przez najbiedniejsze regiony w UE) oraz recesja gospodarcza na świecie, przyczyniła się do drastycznego ograniczenia zawierania kolejnych kontraktów, co w konsekwencji doprowadziło do lawinowego, ponownego wzrostu bezrobocia w tym kraju. Niestety biorąc pod uwagę problemy z ograniczeniem długu publicznego, który gwałtownie wzrósł w Hiszpanii podobnie, jak w innych państwach, trudno się spodziewać szybkich korzystnych zmian, gdyż tak wysokie bezrobocie istotnie ogranicza poziom dochodów publicznych, a także stanowi hamulec dla rozwoju wewnętrznej konsumpcji. $Z$ drugiej zaś strony, wdrażane reformy polegające $w$ dużej mierze na przeprowadzeniu cięć wydatków publicznych, w jeszcze większym stopniu mogą ograniczyć prorozwojowe tendencje $\mathrm{w}$ gospodarce, a to $\mathrm{w}$ prostej linii decyduje o kontynuacji trendu łagodnej recesji. Podobne efekty dla PKB i rynku pracy przyniosła polityka drastycznych oszczędności realizowana w Grecji czy w Słowenii.

Wysoką dynamikę wzrostu bezrobocia (podwojenie stopy) zanotowały również Bułgaria, Dania, Holandia, Portugalia i Słowenia. W przypadku Danii widać z kolei, że zanotowany wzrost bezrobocia do blisko $8,0 \%$ (i tak niższego niż średnia unijna), został szybko powstrzymany, tak by w 2013 roku stopa ukształtowała się na poziomie $6,6 \%$. Taki spadek udało się osiagnąć jedynie nielicznym gospodarkom UE. Rezultat ten osiagnięto nie tylko z uwagi na wypracowane niskie dotychczas tempo wzrostu PKB (1,7\%), ale i dzięki skutecznemu stosowaniu modelu, który określany jest mianem flexicurity. Polityka rynku pracy realizowana w tym modelu zmierza do osiagnięcia równowagi między elastycznością a bezpieczeństwem na rynku pracy. Zakłada, że problemy zatrudnieniowe spowodowane niewystarczającą stopą wzrostu gospodarczego powinny być rozwiązywane przede wszystkim poprzez elastyczność rynku pracy, niskie koszty zatrudnienia, gdyż to pracodawcy w długiej perspektywie podejmują decyzję o tworzeniu miejsc pracy. Aktywne instrumenty polityki rynku pracy, mogą natomiast pełnić efektywnie rolę komplementarną $\mathrm{w}$ stosunku do innych środków polityki gospodarczej państwa, gdyż nie wpływają, z wyjątkiem subwencjonowanego zatrudnienia, na popytową stronę rynku pracy. W strategii tej, Duńczycy udowadniają, że możliwe jest jednoczesne utrzymanie wysokiego stopnia zabezpieczenia socjalnego bezrobotnych i uzyskiwania korzystnych wyników w zakresie redukcji bezrobocia. Rezultaty takiej polityki obalają zatem mit o sprzeczności dwóch celów: skuteczności w ograniczaniu bezrobocia i utrzymania wysokiego stopnia zabezpieczenia socjalnego osób pozbawionych pracy. Nie oznacza to jednak, że jedynie w Danii można obserwować taką sytuację, gdyż wysokie zabezpieczenie socjalne nie znajduje się w ścisłym związku z nadmiernym poziomem bezrobocia. Tabela 3. ukazuje udział wydatków socjalnych $\mathrm{w}$ PKB, co stanowi w dużej mierze odzwierciedlenie poziomu polityki osłonowej skierowanej do osób bezrobotnych. 
Udzial wydatków na ochronę socjalną w PKB (\%)

\begin{tabular}{|c|c|c|}
\hline Państwo & 2000 & 2010 \\
\hline Unia Europejska (27) & $:$ & 29,4 \\
\hline Strefa Euro (17) & 26,7 & 30,4 \\
\hline Belgia & 25,4 & 29,9 \\
\hline Bułgaria & : & 18,1 \\
\hline Republika Czeska & 18,8 & 20,1 \\
\hline Dania & 28,9 & 33,3 \\
\hline Niemcy & 29,7 & 30,7 \\
\hline Estonia & 13,9 & 18,1 \\
\hline Irlandia & 13,8 & 29,6 \\
\hline Grecja & 23,5 & 29,1 \\
\hline Hiszpania & 20,0 & 25,7 \\
\hline Francja & 29,5 & 33,8 \\
\hline Chorwacja & $:$ & 20,8 \\
\hline Włochy & 24,6 & 29,9 \\
\hline Cypr & 14,8 & 21,6 \\
\hline Łotwa & 15,7 & 17,8 \\
\hline Litwa & 15,7 & 19,1 \\
\hline Luxemburg & 19,6 & 22,7 \\
\hline Węgry & 19,9 & 23,1 \\
\hline Malta & 16,6 & 19,8 \\
\hline Holandia & 26,4 & 32,1 \\
\hline Austria & 28,3 & 30,3 \\
\hline Polska & 19,7 & 18,9 \\
\hline Portugalia & 20,9 & 27,0 \\
\hline Rumunia & 13,0 & 17,6 \\
\hline Słowenia & 24,1 & 24,8 \\
\hline Słowacja & 19,4 & 18,6 \\
\hline Finlandia & 25,1 & 30,6 \\
\hline Szwecja & 29,9 & 30,4 \\
\hline Wielka Brytania & 26,4 & 28,0 \\
\hline Islandia & 19,2 & 24,5 \\
\hline Norwegia & 24,4 & 25,6 \\
\hline Szwajcaria & 24,6 & 26,6 \\
\hline
\end{tabular}

Źródło: http://epp.eurostat.ec.europa.eu/portal/page/portal/eurostat/home/, dostęp: 8.10.2013.

Zestawienie zawarte w tabeli 3. wskazuje, że pierwsza dekada XXI wieku przyniosła w niemal wszystkich europejskich państwach wzrost udziału wydatków socjalnych w PKB. Wyjątek stanowią Polska i Słowacja. Głównej przyczyny tej tendencji należy upatrywać przede wszystkim w kryzysie gospodarczym, który od 2008 w wielu 
państwach wywołał recesję i wzrost bezrobocia. Można zatem stwierdzić, że wzrost bezrobocia implikował wzrost wydatków socjalnych a nie odwrotnie, jak sugerują ekonomiści nurtu liberalnego. Ponadto warto zauważyć, że w państwach, w których udział wydatków socjalnych w PKB jest najwyższy i przekracza 30\%: Szwecja, Finlandia, Dania, Holandia, Austria, Francja i Niemcy, rozmiary bezrobocia należą do relatywnie niskich (od 4,9\% w Austrii i 5,2\% w Niemczech do 8\% w Szwecji i Finlandii). Wyjątek w tej grupie stanowi Francja, która notuje bezrobocie na poziomie wyższym, niż średnia unijna $-11 \%$. Powyższe dane pozwalają sformułować wniosek, że hojna, mądrze wrażana polityka osłonowa nie musi generować wzrostu bezrobocia, a wręcz przeciwnie sprzyja wzrostowi globalnego popytu i przyczynia się do ograniczenia jego rozmiarów.

Analizując dynamikę bezrobocia w okresie kryzysu warto zwrócić uwagę na swoisty fenomen, jaki stanowią Niemcy, które poza minimalnym (o 0,3 p.p.) wzrostem w 2009 roku, notowały w całym badanym okresie (2007-2013) niemal systematyczny spadek bezrobocia (z 8,2\% w 2007 r. do 5,2\% w 2013 r.). Można nawet zaryzykować stwierdzenie, że niemiecki rynek pracy zyskuje na kryzysie w UE. Najsilniejsza gospodarka w strefie Euro korzysta z przewag nad osłabionymi gospodarkami południowej Europy, które nie są w stanie odzyskać konkurencyjności poprzez dewaluacje walut krajowych, które są możliwe jedynie w przypadku państw pozostających poza „strefą Euro". Bez wątpienia, główny przykład stanowi w tym miejscu Polska, która utrzymała mimo spowolnienia gospodarczego wysoki stopień konkurencyjności, który zawdzięcza ponad 40-procentowej dewaluacji złotego. Potwierdzający sformułowany wniosek, odmienny przykład stanowi Słowacja, która osiagnnęła blisko 15-procentową stopę bezrobocia. Obok głębokiej recesji $(-8,1 \%)$, przyczyn tak silnego przyrostu liczby poszukujących pracy upatrywać należy w niekorzystnym momencie przystąpienia do „strefy Euro". Przyjęcie wspólnej waluty w tym czasie pozbawiło Słowację możliwości zwiększania konkurencyjności poprzez osłabienie waluty krajowej, co dla relatywnie słabych gospodarek w okresie kryzysu stanowiło istotny instrument minimalizujący koszty ogólnoświatowej dekoniunktury.

Inna, warta uwagi zależność poziomu bezrobocia dotyczy wydatków na aktywną politykę rynku pracy. Programom aktywizującym bezrobotnych często zarzuca się, że przyczyniają się do poprawy sytuacji tylko tymczasowo, a nawet sprzyjają utrwalaniu bezrobocia, poprzez wydłużanie czasu posiadania prawa do zasiłku i tym samym okresów pozostawania bez pracy. Takie tezy znajdują uzasadnienie w niektórych przykładach np. Hiszpania i Irlandia. W innych (Dania, Holandia, Finlandia) z kolei widać, że im wyższy udział w PKB wydatków na ten cel, tym większa równowaga rynku pracy w danym kraju. Wykres 2. wskazuje, że nie występuja jednoznaczne związki rozmiarów bezrobocia i poziomu wydatków na politykę rynku pracy.

Podsumowując, bardziej podatnymi na wzrost bezrobocia okazały się rynki znacząco uelastycznione, ale jednocześnie pozbawione lub w niewielkim stopniu nasycone instrumentami bezpieczeństwa zatrudnienia (zasad flexicurity), gdyż kryzys wywiera wyjątkowo niekorzystny wpływ na niektóre grupy w strukturze zatrudnionych. W pierwszej kolejności, niemal bez ograniczeń następuje redukcja zatrudnienia wśród pracowników na umowach na czas określony (umowy te zwykle w okresie dekoniunktury nie ulegają odnawianiu). W równie trudnej sytuacji znajdują się osoby młode, poszukujące pierwszego zatrudnienia, gdyż wstrzymanie inwestycji i ograniczenia 
Wykres 2. Udzial wydatków na politykę rynku pracy w PKB a stopa bezrobocia

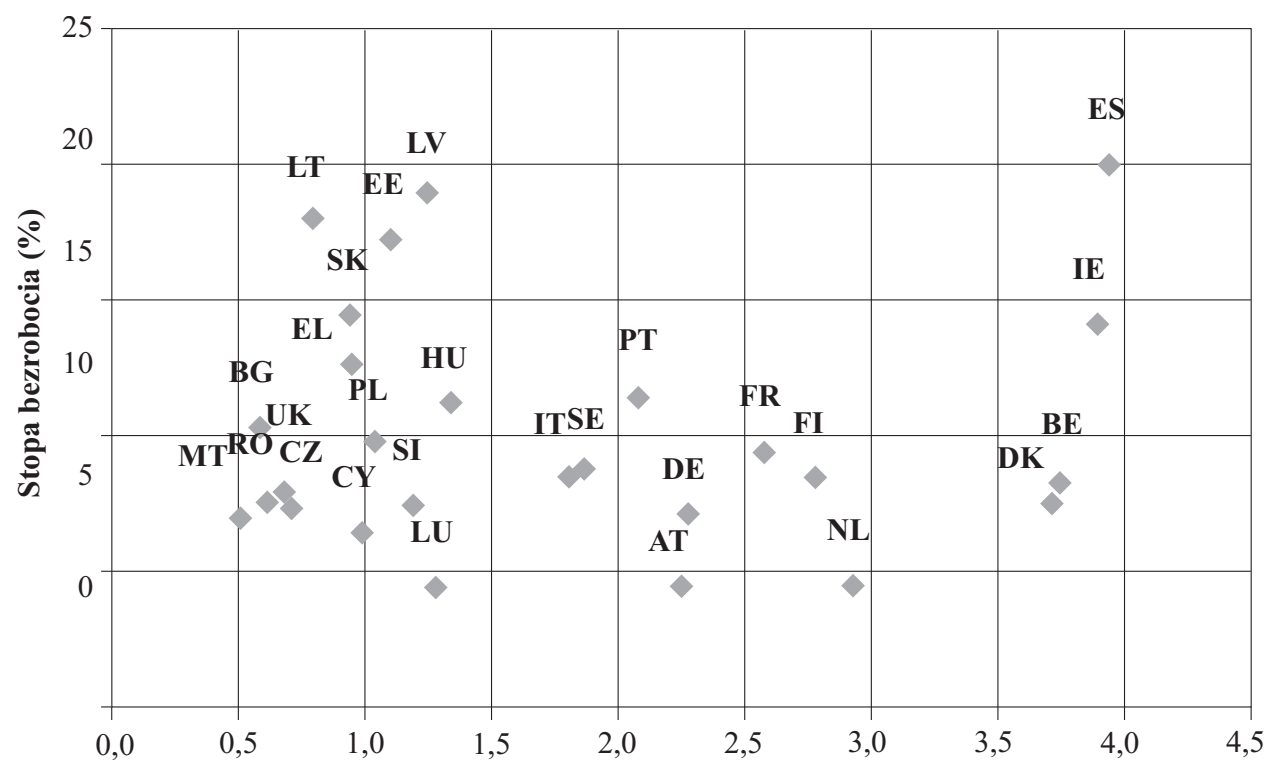

Źródło: http://epp.eurostat.ec.europa.eu/statistics_explained/index.php/Labour_market_policy_expenditure, dostęp: 5.10 .2013 .

wydatków nie sprzyjają tworzeniu nowych miejsc pracy. W tej grupie zanotowano rekordowe stopy bezrobocia, co obrazuje tabela 4 .

Tabela 4

Stopa bezrobocia wśród osób do 25 roku życia

\begin{tabular}{||l|c|c||}
\hline \multirow{2}{*}{ Państwo } & \multicolumn{2}{c|}{ Stopa bezrobocia mlodzieży (\%) } \\
\cline { 2 - 3 } & $\mathbf{2 0 1 0}$ & IV kw. 2012 \\
\hline Unia Europejska (27) & 2 & 3 \\
\hline Strefa Euro (17) & 21,1 & 23,2 \\
\hline Belgia & 20,9 & 23,7 \\
\hline Bułgaria & 22,4 & 22,0 \\
\hline Republika Czeska & 21,8 & 28,4 \\
\hline Dania & 18,3 & 19,3 \\
\hline Niemcy & 14,0 & 14,2 \\
\hline Estonia & 9,9 & 7,9 \\
\hline Irlandia & 32,9 & 19,3 \\
\hline Grecja & 27,6 & 29,4 \\
\hline Hiszpania & 32,9 & 57,9 \\
\hline Francja & 41,6 & 55,2 \\
\hline Włochy & 23,6 & 25,4 \\
\hline Cypr & 27,8 & 36,9 \\
\hline Łotwa & 16,6 & 31,8 \\
\hline
\end{tabular}




\begin{tabular}{||l|c|c||}
\hline \multicolumn{1}{|c|}{1} & 2 & 3 \\
\hline Litwa & 35,3 & 24,2 \\
\hline Luxemburg & 15,8 & 18,5 \\
\hline Węgry & 26,6 & 28,8 \\
\hline Malta & 13,1 & 14,5 \\
\hline Holandia & 8,7 & 9,8 \\
\hline Austria & 8,8 & 8,7 \\
\hline Polska & 23,7 & 27,5 \\
\hline Portugalia & 27,7 & 38,4 \\
\hline Rumunia & 22,1 & 22,2 \\
\hline Słowenia & 14,7 & 23,2 \\
\hline Słowacja & 33,9 & 35,1 \\
\hline Finlandia & 21,4 & 19,3 \\
\hline Szwecja & 24,8 & 24,1 \\
\hline Wielka Brytania & 19,6 & 20,7 \\
\hline \hline
\end{tabular}

Źródlo: http://epp.eurostat.ec.europa.eu/statistics_explained/index.php/Unemployment_statistics, dostęp: 9.10.2013.

Jak wynika z tabeli 4, bezrobocie w UE, wśród osób do 25 roku życia, czyli przede wszystkim osób wchodzących na rynek pracy przeciętnie jest około dwukrotnie wyższe, niż stopa bezrobocia ogółem. Jeszcze gorzej dla tej grupy sytuacja przedstawia się w Szwecji i we Włoszech, gdzie stopy bezrobocia wśród osób młodych stanowią 3-krotność stóp ogółem. Świadczy to o niskiej skuteczności programów wspierających zatrudnienie absolwentów szkół. Zatrudnianiu osób wchodzących na rynek pracy nie sprzyja również nadmierna sztywność rynku pracy, gdzie ochrona dotychczasowych miejsc pracy ogranicza mobilność w zatrudnieniu, co stawia niedoświadczonych poszukujących pracy w pozycji upośledzonych. Rekordowe stopy bezrobocia w tej grupie zanotowano natomiast w Hiszpanii i Grecji (ponad 55\%). Hiszpania jest z kolei przykładem państwa, w którym elastyczność rynku pracy nie zapobiegła ukształtowaniu się dualnego rynku pracy insi der-outsider, na którym absolwenci szkół mają niewielkie szanse w konkurencji o stabilne zatrudnienie z bardziej doświadczonymi, starszymi pracownikami.

W tym miejscu ponownie należy zwrócić uwagę na szczególny przypadek, który stanowi niemiecki rynek pracy. Niemiecki model dowodzi, że można prowadzić skuteczną politykę przeciwdziałania bezrobociu wśród osób młodych (do 25 roku życia). Stopa bezrobocia w tej grupie jedynie nieznacznie (o 2,7 p.p.) przekracza stopę ogółem. Świadczy to o tym, że Niemcy potrafią dostosować oraz powiązać system kształcenia, szczególnie zawodowego z potrzebami rynku pracy i to przede wszystkim decyduje o ich sukcesie w tym segmencie rynku pracy.

Analizując sytuacje na polskim rynku pracy należy zauważyć natomiast, że bezrobocie w okresie światowej recesji wzrosło w Polsce, relatywnie w stosunku do wielu innych państw europejskich nieznacznie (z 8,2\% w 2007 r. do 10,3\% w 2013 r.). Podstawowej przyczyny, tak „korzystnej sytuacji” upatrywać należy z całą pewnością, w utrzymaniu dodatniej dynamiki PKB. Istotną rolę w podtrzymaniu wzrostu gospodarczego oraz wzrostu zatrudnienia odegrało osłabienie polskiej waluty, co zdecydo- 
wało o zwiększeniu konkurencyjności eksportu, ograniczając jego spadek (poziom eksportu zniżkował w większości gospodarek UE pod wpływem recesji).

Uznając poziom wzrostu bezrobocia w Polsce za stan relatywnie korzystny w okresie światowego kryzysu należy wspomnieć jeszcze inne determinanty utrzymania takich poziomów. Jednym z najważniejszych uwarunkowań jest sytuacja demograficzna. Tak, jak na przełomie wieków stanowiła ona główną przyczynę wzrastającego bezrobocia, tak obecnie obserwowany niż demograficzny wśród wchodzących na rynek pracy ogranicza podaż pracy. Wyższy wskaźnik urodzeń w roku 2009 z kolei, miał również korzystne reperkusje dla stabilności rynku pracy, gdyż ograniczył liczbę pracujących kobiet.

Wprawdzie Polska nie doświadczyła dotychczas recesji gospodarczej, to jednak nawet spowolnienie wzrostu PKB wywołało efekt w postaci rozrostu szarej strefy gospodarczej, która mimo, że nie generuje wzrostu legalnego zatrudnienia, podnosi możliwości nabywcze społeczeństwa, zwiększając popyt.

Kolejny determinant to intensyfikacja wykorzystywania środków unijnych w szczególności w okresach przedwyborczych (wybory 2010 i 2011), co sprzyjało inwestycjom infrastrukturalnym. Ponadto realizacja inwestycji budowlanych związanych z piłkarskimi mistrzostwami „Euro 2012”.

Dodać należy, że nawet w okresie spowolnienia gospodarczego, w Polsce zaobserwować można także korzystne implikacje wystapienia tej fazy cyklu koniunkturalnego dla kondycji gospodarki i rynku pracy. Coraz więcej małych i średnich firm, by ustrzec się przed negatywnymi efektami kryzysu stara się wdrażać nowe technologie, nowe rozwiązania w systemie zarządzania, podnosząc tym samym swoją konkurencyjność. Nakłady na inwestycje w środki trwałe oraz na badania i rozwój przekładają się na wyniki finansowe, co potwierdzają badania przeprowadzone przez PKPP Lewiatan. Zgodnie z nimi, aż $61 \%$ firm, które mimo spowolnienia gospodarczego inwestowały w badania i rozwój, zwiększyło swoją konkurencyjność na rynku, a 29\% odnotowało wzrost liczby klientów. Poprawiło jakość swoich usług z kolei 23\%, a jakość oferowanych produktów $41 \%$. Nadal, niestety nakłady innowacyjne w Polsce są znacznie niższe, niż w innych krajach Unii Europejskiej. Ich wartość, przypadająca na głowę jednego Polaka wynosiła w 2008 r. 20,3 euro i była trzykrotnie niższa, niż średnia unijna (61,2 euro) (Innowacyjna strona kryzysu, 2011). Wprawdzie same inwestycje innowacyjne nie muszą korzystnie wpływać na wzrost zatrudnienia, gdyż mogą powodować nawet wzrost bezrobocia technologicznego, to jednak per saldo, przyczyniając się do poprawy konkurencyjności gospodarki, innowacyjność dynamizuje wzrost gospodarczy i przyczynia się do wzrostu zatrudnienia.

Podsumowując sytuację na europejskim rynku pracy warto podkreślić, że postępujący proces uelastyczniania rynku pracy sprzyja konkurencyjności gospodarek Unii Europejskiej. Nie oznacza to jednak, że jako rezultat obserwowanych zmian nie pojawiają się negatywne efekty (przykład Hiszpanii). Konieczne wydaje się zatem dalsze ograniczanie barier przepływu siły roboczej i usług w ramach Unii Europejskiej i wykorzystywanie jednoznacznie pozytywnych doświadczeń reform rynku pracy.

Jako podstawowe zagrożenie dla stabilności zarówno gospodarek, jak i rynków pracy państw UE wskazać należy pogarszanie się sald budżetowych. Obecna sytuacja jest wynikiem nie tylko przebytej recesji oraz niskiego poziomu wzrostu PKB, ale i w dużej 
mierze wydatków przekazywanych instytucjom finansowym, w ramach pakietów stabilizacyjnych. Kraje „strefy Euro” łącznie przeznaczyły na ten cel środki równe ok. 23\% PKB strefy, co oznacza poważne obciążenie dla budżetów poszczególnych krajów, a w konsekwencji dla podatników. Oznacza to jednocześnie konieczność realizacji głębokich reform, mających na celu uzyskanie oszczędności w wyniku ograniczeń wydatków budżetowych. Radykalne cięcia przyczyniają się do ograniczenia popytu a w konsekwencji sprzyjają wydłużaniu czasu trwania drugiej fali kryzysu, co pogarsza sytuację na rynku pracy. Jeżeli nawet większości gospodarkom państw UE udaje się unikać recesji i następuje powolny wzrost zatrudnienia w sektorze rynkowym, to wdrażane programy cięć wydatków budżetowych wywołują ograniczenia zatrudnienia w sektorze publicznym. W związku z tym, w moim przekonaniu nie należy spodziewać się w bliskiej perspektywie wyraźnej poprawy sytuacji na unijnym rynku pracy i osiagnięcia poziomów zatrudnienia bliskich tym, które notowano w okresie przed kryzysem.

\section{Bibliografia}

Choragwicka B. (2006), Droga do Europy - hiszpańskie zmagania z bezrobociem, IPiSS, Warszawa, s. 37.

Czepulis-Rutkowska Z. (2005), Nietypowe formy zatrudnienia a zabezpieczenie społeczne. Czy realizowana jest koncepcja flexicurity?, w: Elastyczny rynek pracy i bezpieczeństwo socjalne. Flexicurity po polsku?, (red.) M. Rymsza, Warszawa, s. 53.

GUS (2013), http://www.stat.gov.pl/GUS, dostęp 10.09.2013.

Innowacyjna strona kryzysu (2011), „Dziennik Gazeta Prawna”, 9 września.

Strauss-Kahn D. (2011), $30 \mathrm{mln}$ ludzi na świecie straciło pracę, http://biznes.newsweek.pl/ 30-mln-ludzi-na-swiecie-stracilo-prace-przez-kryzys,67316,1,1.html, Algadir, PAP, dostęp 31.09.2013.

Zięba J. (2011), Dlugo- i krótkookresowa składowa Produktu Krajowego Brutto wedtug metody Blanchrda i Quaha, http://www.nbp.pl/publikacje/materialy_i_studia/155.pdf, dostęp 20.09.2011.

\section{Streszczenie}

Poziom bezrobocia jest ściśle związany z dynamiką rozwoju PKB. Notowany w UE i w innych państwach świata wzrost stopy bezrobocia począwszy od 2008 potwierdza silną, wzajemną zależność tych wskaźników. Przeprowadzona analiza danych statystyki wykazała, że intensywność przyrostu liczby bezrobotnych w okresie kryzysu jest najwyższa na rynkach najbardziej uelastycznionych, gdzie jednocześnie nie funkcjonują skutecznie, zalecane przez UE zasady modelu flexicurity. Dane poddane badaniu sugerują ponadto, że w najtrudniejszej sytuacji w tych krajach znajdują się wchodzący na rynek pracy absolwenci. Do zaskakujących wniosków doprowadziło z kolei zestawienie poziomu wydatków socjalnych i wydatków na aktywne programy rynku pracy z rozmiarami bezrobocia. Analiza podważyła założenia bliskie koncepcjom rynkowym, gdyż wyższe wydatki na te cele wcale nie towarzyszyły wysokim rozmiarom bezrobocia w okresie przed kryzysem. Skłania to do refleksji i sugeruje, że rosnące wydatki socjalne w okresie kryzysu stanowią jedynie następstwo wzrostu bezrobocia a nie odwrotnie, jak sugerują zwolennicy doktryn liberalnych. 


\section{Summary \\ Unemployment in the European Union in the perspective of the economic crisis of 2008-2013}

The unemployment level is strictly related to the dynamics in GDP. The increasing unemployment rate recorded from 2008 in the EU and other countries around the world corroborates the strong mutual relation of these indices. An analysis of statistics has demonstrated that the increase in the number of the unemployed during a time of crisis is highest in the most flexible markets which are also deprived of the efficient principles of the flexicurity model recommended by the EU. Additionally, the examined data indicate that school graduates entering the labor markets in these countries are in the most difficult position. Other surprising conclusions resulted from a comparison of the level of social expenditure and the cost of labor market programs to the unemployment rate. The analysis undermined the assumptions of the market economy, as higher expenditure for these purposes was not accompanied by high unemployment rates before the crisis. This calls for consideration, and is indicative of the fact that increasing social expenses during a crisis are only a consequence of an increasing unemployment rate, rather than the other way round, as suggested by the proponents of liberal doctrines. 
